\title{
WHITHER DEMOCRATIC LEGITIMISM?: CONTEXTUALIZING RECENT DEVELOPMENTS IN THE RECOGNITION AND NON-RECOGNITION OF GOVERNMENTS
}

\author{
Brad R. Rotb*
}

\section{Introduction: De Wet on the Winding Road of the Democratic Entitlement}

Erika de Wet has provided a useful and balanced assessment ${ }^{1}$ of the current state of the international law of governmental illegitimacy. Her account quite rightly concludes that "democratic legitimacy is not yet a requirement for the recognition of a de jure government under customary international law." What follows below seeks to expand on her observations in two ways: by developing somewhat further the doctrinal linkages to which she alludes; and by explaining the failure of a consistently legitimist state practice to materialize, in light of the dynamics of the legal order within which the question of governmental illegitimacy is embedded. ${ }^{2}$

Professor de Wet invokes a series of conceptual relationships that merit closer attention: (a) between "recognition" of a government and acknowledgment of its status for purposes of international law; (b) between exceptions to the traditional doctrine of "effective control through internal processes" and constitutional or "democratic" legitimism; (c) between acknowledgment of status and the licensing of forcible intervention "by invitation"; (d) between the interstate jus ad bellum at the core of the post-World War II peace and security order and an incipient notion of intrastate jus ad bellum that would not merely augment, but transform, that order.

As de Wet reports, international reactions to internal crises lack the definitive trajectory that democratic legitimism's enthusiasts might have extrapolated from particular post-Cold War developments. That anticipated trajectory would presuppose far simpler social realities than obtain, either among states or within them. The real question is whether the international system will settle on more modest alterations of traditional approaches, or whether an outright incoherence will beset the international system and invite adventurism on the part of powers that have an extraterritorial capacity to impose solutions.

\footnotetext{
* Professor of Political Science and Law at Wayne State University.

Originally published online 21 Jan. 2015.

${ }^{1}$ Erika de Wet, From Free Town to Cairo via Kiev: The Unpredictable Road of Democratic Legitimacy in Governmental Recognition, 108 AJIL UNBOUND 201 (2015).

2 BRAD R. ROTH, GOVERNMENTAL ILLEGITIMACy IN INTERNATIONAL LAW (2000).
} 


\section{Recognition and the International Legal Status of Governments}

It is first necessary to clarify the ambiguities of the term "recognition" as applied to governments. There is a persistent dysfunction in international legal scholarship in regard to "recognition." The discussion traditionally begins with the question "what is recognition?" and only then proceeds to the question "what, if any, are recognition's legal effects?" A more useful starting point (at least insofar as the international order is presupposed to be systemic) would be the question "what is the legal problem to which recognition supplies the solution?" The latter approach would yield the category that de Wet calls "recognition of de jure governments," but that I will herein call, for the sake of clarity, "legal acknowledgment" as distinct from "recognition."

Recognition is often regarded as a discretionary act, and many foreign ministries have purported to "abolish" the practice of recognizing governments. Be that as it may, states do not have discretion to remain oblivious to the international legal status of a governmental apparatus that purports to act on behalf of a foreign state, but rather must take a position on the authenticity of the claimed status whenever confronted with a legal question that turns on that status. States are bearers of international legal rights, obligations, powers, and immunities; governments assert rights, incur obligations, exercise powers, and confer immunities on behalf of states. This principal/agent relationship is foundational to international legal order, and however "objective" the criteria of the agency relationship's authenticity are supposed to be, these criteria do not apply themselves.

Ordinarily, recognition can be seen as a sufficient, but not necessary, indication of a state's legal judgment as to the status of a foreign state or government. However, in some cases-for example, the continued widespread recognition of Afghanistan's "Rabbani Government" (i.e. the Northern Alliance) during the several years when the Taliban held effective control of most of the national territory and population-even a conferral or continuation of formal recognition may not be tantamount to an acknowledgment of authentic legal status. Although "recognition" of governments—as of states—is said to be "declaratory" rather than "constitutive" of status, a widespread and substantially uniform opinio juris as to the apparatus' status cannot be gainsaid without chaotic consequences, and formal recognition remains the most perceptible (albeit not the only) indicator of that opinio juris.

Recognition is thus a major prize. In 2011, when Libya's armed opposition won recognition from major states $^{3}$ as the legitimate government, even while its military prospects remained uncertain, it gained access to Libyan state assets held in foreign banks. By contrast, when President Obama "recognized" the National Coalition of Syrian Revolutionary and Opposition Forces as "the legitimate representative of the Syrian people" in December 2012, the State Department scampered to clarify ${ }^{4}$ the very next day that "[t]his is a political step, not a legal step," pointing out that the announcement did not bear on the territorial and property issues that turn on recognition of governments. The United States thus explicitly withheld acknowledgment of legal standing of the opposition coalition to act in the name of the Syrian state.

\section{The Defining Characteristic of an "Illegitimate" Government: Unconstitutional, Undemocratic, or Manifestly Repudiated?}

It is important not to confuse two distinct legitimist appeals: to a state's positive constitutional norms and to the international community's (supposed) democratic principles. Constitutional legitimism per se is nothing

3 US Recognises Libyan Rebel TNC as Legitimate Authority, BBC NEWs (July 15, 2011).

${ }^{4}$ Carl Schreck, US Stops Short of Legal Recognition of Syrian Rebels, LiVE LEAK (Dec. 13, 2012). 
more or less than a formula for locking in established elites that have formalized their authority. Even rather blatantly undemocratic regimes may maintain the trappings of constitutionality, either through a constitutional licensing of undemocratic practices or through extralegal methods that coexist with constitutional processprocesses. This may explain constitutional legitimism's occasional popularity among undemocratic leaderswho may prefer not to see a fellow leader unceremoniously ousted, lest the bad example prove infectious.

Democracy requires, for its long-term preservation, a fixed constitutional order. However, not only does it not follow that any given fixed constitutional order is actually democratic; it also does not follow that democrats are bound to remain loyal even to ostensibly democratic ground rules. Democrats value particular procedures because - and only insofar as - these seem calculated to reflect genuine popular will and to effectuate governmental accountability to a democratic polity's presumed essential interests and principles (including fundamental human rights). Where, in given circumstances, observance of procedural norms is perceived to frustrate democracy's underlying purposes, such observance tends to be suspended; as the cliché goes, democracy "is not a suicide pact." Thus, it is hardly unknown for putative democrats to support either an overthrow of an elected constitutional government (as, most recently, in Ukraine) or an elected leadership's unconstitutional measures (as in Russia in 1993).

The problem with "genuine democracy" as the criterion for governmental legitimacy is that when democracy is understood to be unmoored from fixed procedures, there is no clear basis for adjudicating competing claims of both sides to the democratic high ground. Ultimately, we do not know what democracy is until we know what it is for, and there turns out to be no consensus about democracy's underlying purposes, especially as applied to circumstances of polarization and crisis.

There is, however, a greater prospect of consensus on what democracy is not. The existence of twilight does not refute the distinction between day and night. Where a regime is widely perceived, from across ideological and cultural divides, to have been manifestly repudiated by the subject population, an aspect of democratic principles can be upheld-over and against the rule of "effective control through internal processes" - without recourse to parochialism. Thus, the cases of Haiti (1991-94) and Sierra Leone (1997-98) can be explained as modest qualifications to the effective control doctrine-instances in which a presumption of popular acceptance of the effective regime is rebutted to the satisfaction of an ideologically diverse international community.

The third major legally sanctioned armed intervention to enforce an electoral outcome-in Côte d'Ivoire (2010-11), against Laurent Gbagbo's government following its 54\% to 46\% electoral defeat—is more difficult to explain in these terms, as the society was manifestly divided. Nonetheless, Côte d'Ivoire was distinctive in (1) having already been the object of Chapter VII resolutions aimed at resolving a sectional civil war, and (2) having been the site of an externally brokered agreement calling both for elections organized in a specific manner and for the parties to abide by an internationally backed body's electoral adjudication.

Thus, whereas de Wet sees a failure of the international community to observe pro-democratic precedent in Ukraine, Egypt, Mali, and other cases, one can alternatively regard the exception to the effective control doctrine as having been much more limited in the first place. Popular sovereignty is a broader concept than democracy, one that admits of a strong presumption in favor of established patterns of rule, absent indications of manifest repudiation by the subject population.

\section{Armed Intervention by Invitation of the Legitimate Government}

An international legal doctrine of governmental illegitimacy has its greatest potential impact in regard to the question of sovereign consent to the foreign use of force within national territory. Cross-border uses of force are precluded where these violate "the territorial integrity or political independence of any state", but 
where forcible intervention is authorized by an invitation validly attributable to the sovereign political community, the prohibition does not apply. Thus, in principle, a doctrine of governmental illegitimacy can lay the groundwork for an external use of force against the will of a de facto government, even absent a Chapter VII authorization.

Intervention by invitation presents issues more complex than commonly supposed. Traditional doctrine conferred the capacity of sovereign consent on the holder of "effective control through internal processes" as a proxy for what Thomas Jefferson once called "the will of the people, substantially declared." It has thus often been suggested that as soon as effective control has been vitiated or has become closely contested, the putative government can no longer unilaterally consent for the state to intervention that might determine the outcome of the internal struggle; rather, the default position ${ }^{5}$ shifts to an international obligation of neutrality, with peacekeeping or humanitarian operations proceeding only by mutual consent of the warring parties. If this suggested corollary has scarcely been felt in practice, ${ }^{6}$ it may be because where an insurgent force has demonstrated sufficient capacity to shake the hold of an established government (able lawfully to draw on foreign assistance in the first instance), it has typically done so with inadmissible foreign assistance, thereby licensing counter-intervention in favor of the established government. At any rate, the legal capacity of a recognized, or even legally acknowledged, government to invite intervention should not be regarded as doctrinally automatic, even though it has generally held up in practice.

To be sure, where the government's status is predicated more directly on a manifestation of popular willsuch as, in the quintessential 1991-94 Haitian case, an overwhelming, recent, and internationally verified electoral mandate- the loss of effective control should be far less relevant. Moreover, even absent any electoral mandate, some armed challenges to governmental authority lack any plausible grounding in popular will (e.g., the 2012-13 insurgency in Northern Mali). Still, the foundational principle of each state's "inalienable right to choose its own political, economic, social, and cultural systems, without interference in any form" properly entails a presumption (albeit rebuttable) that crises of governmental authority are "essentially within the domestic jurisdiction." A clear popular mandate for a wholly non-efficacious governmental apparatus to invite foreign forces to establish or re-establish its efficacy will be the exceptional case.

Moreover, even where a given governmental order as a whole can speak unilaterally for the state, there is often reason to question whether a head of state or head of government can speak unilaterally for that governmental order in inviting foreign troops onto national territory. Where an elected President is unconstitutionally ousted by an elected legislature (as in Honduras in 2009 or Ukraine in 2014), there is guaranteed (almost irrespective of the actual language of the constitution) to be an "objectively evident" constitutional doubt about such Presidential authority-let alone (as in the Crimea example) where exercised with the effect of ceding national territory to a foreign power.

\section{Intrastate Jus ad Bellum: Not Merely Beyond, but Against, Traditional Doctrine}

The twentieth century architecture of international peace and security law was designed to prevent war among states. The imperative "to save succeeding generations from the scourge of war, which twice in our lifetime has brought untold sorrow to mankind" was limited to interstate war, not because internal armed conflict did not register, but because the scheme conceptualized great-power licenses to intervene in the internal affairs of weaker states as a problem rather than a solution- not less so, but all the more so, when those weaker states were beset by internal armed conflict. The civil wars that marked the ensuing era of Cold

\footnotetext{
${ }^{5}$ Institut de Droit Internaitonal, Le principe de non-intervention das les guerres civilizes, resolution from the Session of Wiesbaden (1975).

${ }^{6}$ Louise Doswald-Beck, The Legal Validity of Military Intervention by Invitation of the Government, 56 BRIT. Y.B. INT'L L. 189 (1985).
} 
War and decolonization only reinforced this jurisprudential mindset. Guided by the principle of respect for the territorial political community's self-determination, the international legal order sought above all to assure that power struggles be resolved by authentically internal processes, be those based on ballots or bullets. The system's objective was to reinforce the geographical boundaries of legitimate intrastate violence, rather than to suppress violence as such.

Thus, the concept of jus ad bellum designedly had no application to internal conflict. Insurgents could not lawfully be aided and enjoyed no international protection (other than the truncated set of jus in bello standards applicable to non-international armed conflicts), but international law did not seek affirmatively to constrain them from taking their best shot at seizing power, nor to deprive them of success should they achieve it.

Contrary to what is sometimes imagined, the international legal order is not a legal order of legal orders; it is a legal order of sovereign political communities, each of which bears an "inalienable" capacity - by virtue of its "inalienable right to choose its own political, economic, social, and cultural systems, without interference in any form" " - to overthrow any existing domestic order by any means. The crucial question is whether the overthrow is authentically attributable to the sovereign political community-a question as to which factors beyond "effective control through internal processes" are increasingly coming to be relevant.

"Effective control through internal processes" emerged as a test suggested not merely by convenience and convention, but by an application of the principle of popular sovereignty in a pluralistic international community numerically dominated (as was the case until very recently) by governments tracing their origins directly to revolutions, coups, and civil wars. Popular acquiescence in a pattern of governance was deemed to validate that governance for international purposes, not for the naive reason that civil wars are won by the deserving side, but for the tough-minded reason that populaces were presumed to regard foreign interventions as predatory.

To be sure, since the end of the Cold War, this anti-interventionist dogma has given way to greater nuance and flexibility. Still, the default position remains that "successful revolution begets its own legality"8_or, to put it more bluntly, that political communities have the right to be ruled by their own thugs and to fight their civil wars in peace. ${ }^{9}$ Absent a cross-cutting international consensus as to a prevailing regime's inauthenticitya consensus most often associated with a Security Council authorization of intervention-the international order continues to acknowledge the locally prevalent outcome as establishing the regime's capacity to exercise the state's irreducible legal prerogatives (even amid denunciations of the regime's human rights violations or political efforts to isolate the regime). ${ }^{10}$

It is sometimes suggested that the pattern of recent Security Council's Chapter VII edicts in response to internal conflicts establishes a norm against recourse to violence to resolve internal political disputes. ${ }^{11}$ However, absent an antecedent determination about the valid terms of public order in a territory, this is not conceivable: is it resistance to de facto territorial authority, or suppression of that resistance, that counts as the "recourse to violence"? The Security Council can, to be sure, make ad hoc determinations to freeze a particular status quo (much as the international territorial status quo is frozen by the UN Charter), against which all use of force counts as "violence," but such extemporary decrees are a far cry from constituting a generally applicable jus ad bellum for internal conflict. Thus, one cannot be surprised when local contests over political

${ }^{7}$ GA Res. 2625 (XXV) (Oct. 24, 1970).

${ }^{8}$ S. A. de Smith, Constitutional Lanyers in Revolutionary Situations, 7 W. ONTARIO L. REv. 93 (1968).

${ }^{9}$ Brad. R. Roth, Successions, Coups, and the International Rule of Law: Assessing the Decline of the Effective Control Doctrine, 11 MELB. J. INT'L L. 1 (2010).

${ }^{10} \mathrm{Brad}$ R. Roth, Sovereign Equality and Non-Liberal Regimes, 43 NETH. Y.B. INT'L L. 25 (2012).

${ }^{11}$ Kalkidan Obse, The Arab Spring and the Question of Legality of Democratic Revolution in Theory and Practice: A Perspective Based on the African Union Normative Framework, 27 LEIDEN J. INT'L L. 817 (2014). 
legitimacy (such as that in Egypt in 2013) are decided by force and the outcome is accepted (however grudgingly) by the global peace and security order.

\section{Whither Democratic Legitimism?}

De Wet evinces disappointment that recent events in Ukraine, Egypt, and Sub-Saharan Africa have not vindicated the promise of a democratic constitutional legitimism. But these events are mere reminders of what has been clear all along: that one's assessment of the democratic quality of a political act turns ultimately on whether one sees it as serving (long-term) democratic ends. Sincere democrats, rightly and wrongly, have taken a range of views on crises that have pitted plausibly democratic values against one another-for example, the Algerian coup to preempt the electoral victory of illiberal Islamists in 1992;12 Boris Yeltsin's unconstitutional dispersal of the Russian legislature in 1993; the Dayton High Commissioner's removal of Republika Srpska's elected ethno-nationalist president in 1999; the multifarious actions on both sides of the Venezuelan crisis of 2002; the Hamas electoral victory in the Occupied Palestinian Territories in 2006; the legislatively and judicially backed Honduran coup d'etat in 2009; and many more. The overthrows of Morsi and Yanukovych simply add to the list.

Moreover, the international system remains characterized by a multiplicity of conflicting interests and conflicting political moralities, where implementers of supposed universal values are untrusted-and often untrustworthy. And indeed, recent events in Syria and Ukraine suggest at least a partial return to a prevalence of Security Council deadlock. In this context, a thorough-going democratic legitimism is unpromising as an international norm, and a potential source of mischief as a unilateralist initiative (as experiments in regime change periodically remind us).

Yet a pluralist international order, while generally deferential to the outcome of local power struggles, does not require acceptance of whatever blatant thuggery manages to assert itself. "Effective control through internal processes" grounds a rebuttable presumption; legal standing can still be denied to a governmental apparatus whose claim to represent the territorial political community manifestly lacks all plausibility.

${ }^{12}$ Gregory H. Fox \& Georg Nolte, Intolerant Democracies, 36 HARv. InT’L L.J. 1 (1995). 